\title{
Model Policy Concerning College and University Photocopying for Classroom, Research and Library Reserve Use
}

Editor's Note: This model policy was prepared by Mary Hutchings, ALA's legal counsel, in March, 1982.

\section{The Copyright ACt and Photocopying}

From time to time, the faculty and staff of this University [College] may use photocopied materials to supplement research and teaching. In many cases, photocopying can facilitate the University's [College's] mission; that is, the development and transmission of information. However, the photocopying of copyrighted materials is a right granted under the copyright law's doctrine of "fair use" which must not be abused. This report will explain the University's [College's] policy concerning the photocopying of copyrighted materials by faculty and library staff. Please note that this policy does not address other library photocopying which may be permitted under other sections of the copyright law, e.g., 17 U.S.C. $\$ 108$.

Copyright is a constitutionally conceived property right which is designed to promote the progress of science and the useful arts by securing for an author the benefits of his or her original work of authorship for a limited time. U.S. Constitution, Art. I, Sec. 8. The Copyright statute, 17 U.S.C. $\$ 101$ et seq., implements this policy by balancing the author's interest against the public interest in the dissemination of information affecting areas of universal concern, such as art, science, history and business. The grand design of this delicate balance is to foster the creation and dissemination of intellectual works for the general public.

The Copyright Act defines the rights of a copyright holder and how they may be enforced against an infringer. Included within the Copyright Act is the "fair use" doctrine which allows, under certain conditions, the copying of copyrighted material. While the Act lists general factors under the heading of "fair use" it provides little in the way of specific directions for what constitutes fair use. The law states:

17 U.S.C. \$107. Limitations on exclusive rights: Fair use.

Notwithstanding the provisions of section 106 , the fair use of a copyrighted work, including such use by reproduction in copies or phonorecords or by any other means specified by that section, for purposes such as criticism, comment, news reporting, teaching (including multiple copies for classroom use), scholarship, or research, is not an infringement of copyright. In determining whether the use made of a work in any particular case is a fair use the factors to be considered shall include-

(1) the purpose and character of the use, including whether such use is of a commercial nature or is for nonprofit educational purposes;

(2) the nature of the copyrighted work;

(3) the amount and substantiality of the portion used in relation to the copyrighted work as a whole; and

(4) the effect of the use upon the potential market for or value of the copyrighted work. (Emphasis added.)

The purpose of this report is to provide you, the faculty and staff of this University [College], with an explanation of when the photocopying of copyrighted material in our opinion is permitted under the fair use doctrine. Where possible, common examples of research, classroom, and library reserve photocopying have been included to illustrate what we believe to be the reach and limits of fair use.

Please note that the copyright law applies to all forms of photocopying, whether it is undertaken at a commercial copying center, at the University's [College's] central or departmental copying facilities or at a self-service machine. While you are free to use the services of a commercial establishment, you should be prepared to provide documentation of permission from the publisher (if such permission is necessary under this policy), since many commercial copiers will require such proof.

We hope this report will give you an appreciation of the factors which weigh in favor of fair use and those factors which weigh against fair use, but faculty members must determine for themselves which works will be photocopied. This University [College] does not condone a policy of photocopying instead of purchasing copyrighted works where such photocopying would constitute an infringement under the Copyright law, but it does encourage faculty members to exercise good judgment in serving the best interests of students in an efficient manner. This University [College] arid its faculty and staff will make a conscientious effort to comply with these guidelines.

Instructions for securing permission to photocopy copyrighted works when such copying is beyond the limits of fair use appear at the end of this report. It is the policy of this University that the user (faculty, staff or librarian) secure such permission whenever it is legally necessary. 


\section{UNRESTRICTED Photocopying}

\section{A. Uncopyrighted Published Works}

Writings published before January 1, 1978, which have never been copyrighted may be photocopied without restriction. Copies of works protected by copyright must bear a copyright notice, which consists of the letter " $c$ " in a circle, or the word "Copyright", or the abbreviation "Copr.", plus the year of first publication, plus the name of the copyright owner. 17 U.S.C. $\$ 401$. As to works published before January 1, 1978 , in the case of a book, the notice must be placed on the title page or the reverse side of the title page. In the case of a periodical the notice must be placed either on the title page, the first page of text, or in the masthead. A pre-1978 failure to comply with the notice requirements resulted in the work being injected into the public domain, i.e., unprotected. Copyright notice requirements have been relaxed since 1978, so that the absence of notice on copies of a work published after January 1, 1978, does not necessarily mean the work is in the public domain. 17 U.S.C. $\$ 405$ (a) and (c). However, you will not be liable for damages for copyright infringement of works published after that date, if, after normal inspection, you photocopy a work on which you cannot find a copyright symbol and you have not received actual notice of the fact the work is copyrighted. 17 U.S.C. $\$ 405(b)$. However, a copyright owner who found out about your photocopying would have the right to prevent further distribution of the copies if in fact the work were copyrighted and the copies are infringing. 17 U.S.C. $\$ 405(b)$.

\section{B. Published Works With Expired Copyrights}

Writings with expired copyrights may be photocopied without restriction. All copyrights prior to 1906 have expired. 17 U.S.C. \$304(b). Copyrights granted after 1906 may have been renewed; however the writing will probably not contain notice of the renewal. Therefore, it should be assumed all writings dated 1906 or later are covered by a valid copyright, unless information to the contrary is obtained from the owner or the U.S. Copyright Office (see Copyright Office Circular 15t).

Copyright Office Circular R22 explains how to investigate the copyright status of a work. One way is to use the Catalog of Copyright Entries published by the Copyright Office and available in [the University Library] many libraries. Alternatively you may request the Copyright Office to conduct a search of its registration and/or assignment records. The Office charges an hourly fee for this service. You will need to submit as much information as you have concerning the work in which you are interested, such as the title, author, approximate date of publication, the type of work or any available copyright data. The Copyright Office does caution that its searches are not conclusive; for instance, if a work obtained copyright less than 28 years ago, it may be fully protected although there has been no registration or deposit.

\section{Unpublished Works}

Unpublished works, such as theses and dissertations, may be protected by copyright. If such a work was created before January 1, 1978, and has not been copyrighted or published without copyright notice, the work is protected under the new Act for the life of the author plus fifty years, 17 U.S.C. $\$ 303$, but in no case earlier than December 31,2002 . If such a work is published on or before that date, the copyright will not expire before December 31, 2027. Works created after January 1, 1978, and not published enjoy copyright protection for the life of the author plus fifty years. 17 U.S.C. $\$ 302$.

\section{U.S. Government Publications}

All U.S. Government publications with the possible exception of some National Technical Information Service Publications less than 5 years old may be photocopied without restrictions, except to the extent they contain copyrighted materials from other sources. 17 U.S.C. \$105. U.S. Government publications are documents prepared by an official or employee of the government in an official capacity. 17 U.S.C. $\$ 101$. Government publications include the opinions of courts in legal cases, Congressional Reports on proposed bills, testimony offered at Congressional hearings and the works of government employees in their official capacities. Works prepared by outside authors on contract to the government may or may not be protected by copyright, depending on the specifics of the contract. In the absence of copyright notice on such works, it would be reasonable to assume they are government works in the public domain. It should be noted that state government works may be protected by copyright. See, 17 U.S.C. $\$ 105$. However, the opinions of state courts are not protected.

\section{Permissible Photocopying of COPYRIGHTED WORKS}

The Copyright Act allows anyone to photocopy copyrighted works without securing permission from the copyright owner when the photocopying amounts to a "fair use" of the material. 17 U.S.C. $\$ 107$. The guidelines in this report discuss the boundaries for fair use of photocopied material used in research or the classroom or in a library reserve operation. Fair use cannot always be expressed in numbers-either the number of pages copied or the number of copies distributed. Therefore, you should weigh the various factors listed in the Act and judge whether the intended use of photocopied, copyrighted material is within the spirit of the fair use doctrine. Any serious questions concerning whether a particular 
photocopying constitutes fair use should be directed to University [College] counsel.

\section{A. Research Uses}

At the very least, instructors may make a single copy of any of the following for scholarly research or use in teaching or preparing to teach a class:

1. a chapter from a book;

2. an article from a periodical or newspaper;

3. a short story, short essay, or short poem, whether or not from a collective work;

4. a chart, diagram, graph, drawing, cartoon or picture from a book, periodical, or newspaper.

These examples reflect the most conservative guidelines for fair use. They do not represent inviolate ceilings for the amount of copyrighted material which can be photocopied within the boundaries of fair use. When exceeding these minimum levels, however, you again should consider the four factors listed in Section 107 of the Copyright Act to make sure that any additional photocopying is justified. The following demonstrate situations where increased levels of photocopying would continue to remain within the ambit of fair use:

1. the inability to obtain another copy of the work because it is not available from another library or source or cannot be obtained within your time constraints

2 . the intention to photocopy the material only once and not to distribute the material to others;

3 . the ability to keep the amount of material photocopied within a reasonable proportion to the entire work (the larger the work, the greater amount of material which may be photocopied).

Most single-copy photocopying for your personal use in research-even when it involves a substantial portion of a work-may well constitute fair use.

\section{B. Classroom Uses}

Primary and secondary school educators have, with publishers, developed the following guidelines, which allow a teacher to distribute photocopied material to students in a class without the publisher's prior permission, under the following conditions:

1. the distribution of the same photocopied material does not occur every semester;

2. only one copy is distributed for each student which copy must become the student's property;

3 . the material includes a copyright notice on the first page of the portion of material photocopied;

4. the students are not assessed any fee beyond the actual cost of the photocopying.

In addition, the educators agreed that the amount of material distributed should not exceed certain brevity standards. Under those guidelines, a prose work may be reproduced in its entirety if it is less than 2500 words in length. If the work exceeds such length, the excerpt reproduced may not exceed 1000 words, or $10 \%$ of the work, whichever is less. In the case of poetry, 250 words is the maximum permitted.

These minimum standards normally would not be realistic in the University setting. Faculty members needing to exceed these limits for college education should not feel hampered by these guidelines, although they should attempt a "selective and sparing" use of photocopied, copyrighted material.

The photocopying practices of an instructor should not have a significant detrimental impact on the market for the copyrighted work. 17 U.S.C. $\$ 107(4)$. To guard against this effect, you usually should restrict use of an item of photocopied material to one course and you should not repeatedly photocopy excerpts from one periodical or author without the permission of the copyright owner.

\section{Library Reserve Uses}

At the request of a faculty member, a library may photocopy and place on reserve excerpts from copyrighted works in its collection in accordance with guidelines similar to those governing formal classroom distribution for face to face teaching discussed above. This University [College] believes that these guidelines apply to the library reserve shelf to the extent it functions as an extension of classroom readings or reflects an individual student's right to photocopy for his personal scholastic use under the doctrine of fair use. In general, librarians may photocopy materials for reserve room use for the convenience of students both in preparing class assignments and in pursuing informal educational activities which higher education require, such as advanced independent study and research.

If the request calls for only one copy to be placed on reserve, the library may photocopy an entire article, or an entire chapter from a book, or an entire poem. Requests for multiple copies on reserve should meet the following guidelines:

1. the amount of material should be reasonable in relation to the total amount of material assigned for one term of a course taking into account the nature of the course, its subject matter and level, 17 U.S.C. $\$ 107(1)$ and (3);

2 . the number of copies should be reasonable in light of the number of students enrolled, the difficulty and timing of assignments, and the number of other courses which may assign the same material, 17 U.S.C. $\$ 107(1)$ and (3);

3 . the material should contain a notice of copyright, see, 17 U.S.C. $\$ 401$;

4. the effect of photocopying the material should not be detrimental to the market for the work. (In general, the library should own at least one copy of the work.) 17 U.S.C. $\$ 107(4)$.

For example, a professor may place on reserve as a supplement to the course textbook a reasonable number of copies of articles from academic journals or chapters from trade books. A reasonable number of copies will in most instances be less than six, but factors such as the length or 
difficulty of the assignment, the number of enrolled students and the length of time allowed for completion of the assignment may permit more in unusual circumstances.

In addition, a faculty member may also request that multiple copies of photocopied, copyrighted material be placed on the reserve shelf if there is insufficient time to obtain permission from the copyright owner. For example, a professor may place on reserve several photocopies of an entire article from a recent issue of Time magazine or the New York Times in lieu of distributing a copy to each member of the class. If you are in doubt as to whether a particular instance of photocopying is fair use in the reserve reading room, you should seek the publisher's permission. Most publishers will be cooperative and will waive any fee for such a use.

\section{Uses of Photocopied Material Requiring Permission}

1. Repetitive copying: The classroon or reserve use of photocopied materials in multiple courses or successive years will normally require advance permission from the owner of the copyright, 17 U.S.C. $\$ 107(3)$.

2. Copying for profit: Faculty should not charge students more than the actual cost of photocopying the material, 17 U.S.C. $\$ 107(1)$.

3. Consumable works: The duplication of works that are consumed in the classroom, such as standardized tests, exercises, and workbooks, normally requires permission from the copyright owner, 17 U.S.C. $\$ 107(4)$.

4. Creation of anthologies as basic text material for a course: Creation of a collective work or anthology by photocopying a number of copyrighted articles and excerpts to be purchased and used together as the basic text for a course will in most instances require the permission of the copyright owners. Such photocopying is more likely to be considered as a substitute for purchase of a book and thus less likely to be deemed fair use, 17 U.S.C. $\$ 107(4)$.

\section{E. How to Obtain Permission}

When a use of photocopied material requires that you request permission, you should communicate complete and accurate information to the copyright owner. The American Association of Publishers suggests that the following information be included in a permission request letter in order to expedite the process:

1. Title, author and/or editor, and edition of materials to be duplicated.

2. Exact material to be used, giving amount, page numbers, chapters and, if possible, a photocopy of the material.

3. Number of copies to be made.

4. Use to be made of duplicated materials.

5. Form of distribution (classroom, newsletter, etc.).

6 . Whether or not the material is to be sold.
7. Type of reprint (ditto, photography, offset, typeset).

The request should be sent, together with a self-addressed return envelope, to the permissions department of the publisher in question. If the address of the publisher does not appear at the front of the material, it may be readily obtained in a publication entitled The Literary Marketplace, published by the R. R. Bowker Company and available in all libraries.

The process of granting permission requires time for the publisher to check the status of the copyright and to evaluate the nature of the request. It is advisable, therefore, to allow enough lead time to obtain permission before the materials are needed. In some instances, the publisher may assess a fee for the permission. It is not inappropriate to pass this fee on to the students who receive copies of the photocopied material.

The Copyright Clearance Center also has the right to grant permission and collect fees for photocopying rights for certain publications. Libraries may copy from any journal which is registered with the CCC and report the copying beyond fair use to CCC and pay the set fee. A list of publications for which the CCC handles fees and permissions is available from the CCC, 310 Madison Avenue, New York, N.Y. 10017.

\section{Sample Letter To Copyright Owner (Publisher) \\ Requesting Permission To Copy}

March 1, 1982

Material Permissions Department

Hypothetical Book Company

500 East Avenue

Chicago, Illinois 60601

Dear Sir or Madam:

I would like permission to copy the following for continued use in my classes in future semesters:

Title: Learning is Good, Second Edition

Copyright: Hypothetical Book Co., 1965, 1971

Author: Frank Jones

Material to be duplicated: Chapters 10,11 and 14 (photocopy enclosed).

Number of copies: 500

Distribution: The material will be distributed to students in my classes and they will pay only the cost of the photocopying.

Type of reprint: Photocopy

Use: The chapter will be used as supplementary teaching materials.

I have enclosed a self-addressed envelope for your convenience in replying to this request.

$$
\begin{aligned}
& \text { Sincerely, } \\
& \text { Faculty Member }
\end{aligned}
$$

\section{F. Infringement}

Courts and legal scholars alike have commented that the fair use provisions in the Copyright Act are among the most vague and difficult that can be found anywhere in the law. In amending the Copyright Act in 1976, Congress anticipated the problem this would pose for users 
of copyrighted materials who wished to stay under the umbrella of protection offered by fair use. For this reason, the Copyright Act contains specific provisions which grant additional rights to libraries and insulate employees of a non-profit educational institution, library, or archives from statutory damages for infringement where the infringer believed or had reasonable grounds to believe the photocopying was a fair use of the material. 17 U.S.C. $\$ 504(\mathrm{c})(2)$.

Normally, an infringer is liable to the copyright owner for the actual losses sustained because of the photocopying and any additional profits of the infringor. 17 U.S.C. $\$ 504(a)(1)$ and (b). Where the monetary losses are nominal, the copyright owner usually will claim statutory damages instead of the actual losses. 17 U.S.C. $\$ 504(a)(2)$ and (c). The statutory damages may reach as high as $\$ 10,000$ (or up to $\$ 50,000$ if the infringement is willful). In addition to suing for money damages, a copyright owner can usually prevent future infringement through a court injunction. 17 U.S.C. $\S 502$.

\section{Sandy Whiteley \\ ACRL Program Officer}

Since joining ACRL in November, 1981, as a half-time program officer, I have had the interim responsibility for the Bibliographic Instruction Liaison Project. By working with nine scholarly associations, we are trying to educate faculty and administrators about bibliographic instruction (see CURL News, October 1981, pp. 319-20). These organizations are: American Assembly of Collegiate Schools of Business, American Association for Higher Education, American

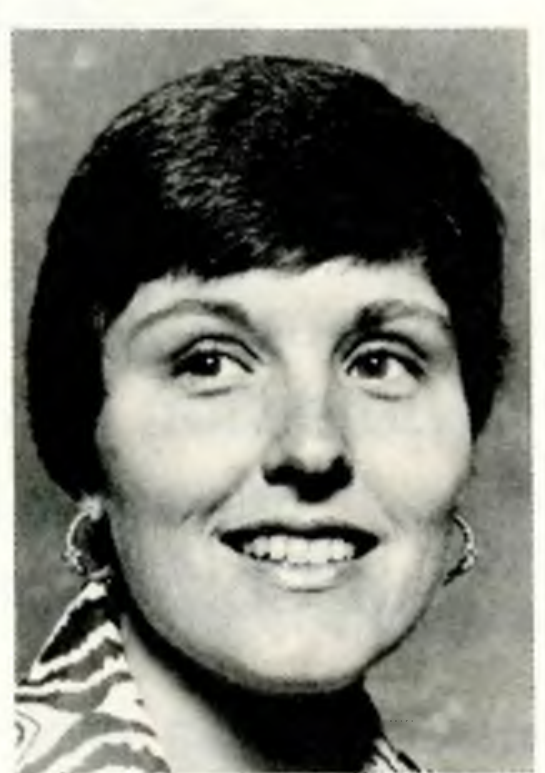

Sandy Whiteley Association for the Advancement of Science, American Council on Education, American Historical Association, American Political Science Association, American Psychological Association, American Sociological Association, and the Modern Language Association.

In March and April, librarians will be giving workshops on library skills in sociology for sociologists attending six regional meetings of the American Sociological Association. The librarians will attempt to have the participating sociologists
The Copyright Act specifically exempts from statutory damages any employee of a non-profit educational institution, library, or archives, who "believed and had reasonable grounds for believing that his or her use of the copyrighted work was a fair use under Section 107." 17 U.S.C. $\$ 504$ (c)(2). While the fair use provisions are admittedly ambiguous, any employee who attempts to stay within the guidelines contained in this report should have an adequate good faith defense in the case of an innocently committed infringement.

If the criteria contained in this report are followed, it is our view that no copyright infringement will occur and that there will be no adverse affect on the market for copyrighted works.

(Many educational institutions will provide their employees legal counsel without charge if an infringement suit is brought against the employee for photocopying performed in the course of employment. If so, this should be noted here.)

\section{The View From HQ}

make a connection between what they have learned in the workshop and what their students need to learn-leading, we hope, to opportunities for bibliographic instruction on their home campuses.

Our proposal to the American Association for Higher Education for a program at their annual meeting was not accepted. We did not submit a proposal to the American Psychological Association because I was unable to find anyone to do a program for them. I would very much appreciate hearing from someone with a background in bibliographic instruction in psychology (especially an APA member or someone with a $\mathrm{Ph} . \mathrm{D}$. in psychology) who would be willing to prepare a proposal for next year's meeting.

We are now preparing for the proposal deadlines for the American Council on Education and the Modern Language Association. We know the meeting places and dates and proposal deadlines for the remaining five organizations and will proceed with them as time permits.

We continue to build our resource file of librarians with experience in bibliographic instruction who are willing to write proposals and give papers at the meetings of professional associations. I wrote to all the committee members of the Bibliographic Instruction Section and the Anthropology and Sociology Section, soliciting participation in the project, and I would like to thank all the people who have responded. We will be getting back to all of you eventually and we would still be happy to receive more names. 